\title{
Pengaruh Financial Distress dan Earning Per Share (EPS) terhadap Return Saham Perusahaan (pada Sub Sektor Perkebunan Kelapa Sawit yang Terdaftar di Bei untuk Periode Tahun 2015-2018)
}

\author{
Reny Dany Merliyana ${ }^{1}$; R. Wedi Rusmawan Kusumah ${ }^{2}$ \\ ${ }^{1}$ Universitas Widyatama \\ rd.merliyana22@gmail.com \\ ${ }^{2}$ Universitas Widyatama \\ wedi.rusmawan@widyatama.ac.id
}

\begin{abstract}
Abstrak
Kajian dalam riset ini bertujuan guna memutuskan dampak Financial Distress dan Earning per Share (EPS) terhadap Return Saham Perseroan (pada Sub Sektor Perkebunan Kelapa Sawit yang tercatat di Bursa Efek Indonesia (BEI) untuk periode penelitian dari tahun 2015 sampai tahun 2018. Faktor yang diuji yaitu Financial Distress dan Earning per Share (EPS) sebagai variabel bebas dan Return Saham sebagai variabel terikat. Riset ini menggunakan pengukuran dari skala rasio dan Purposive Sampling, sehingga terdapat 15 emiten sub sektor Perkebunan Kelapa Sawit yang tercatat di Bursa Efek Indonesia dalam riset ini. Pengkajiannya menggunakan Statistik Deskriptif melalui teknik regresi data panel yang menggunakan prosedur pengujian Random Effect Model atau REM melalui aplikasi pengujian pemrograman Eviews 9. Setelah dilakukan pengujian, terdapat hubungan yang negatif dari penggunaan model Zmijewski untuk menguji faktor Financial Distress pada Return Saham. Sedangkan, faktor Earning per Share (EPS) tidak memiliki pengaruh pada Return Saham. Diketahui juga bahwa PT Astra Agro Lestari, Tbk (AALI) memiliki kinerja keuangan dan nilai saham yang terbaik, sedangkan PT Gozco Plantation, Tbk (GZCO) memiliki performa keuangan dan nilai saham yang paling buruk bila dibandingkan dengan asosiasi Sub Sektor Perkebunan Kelapa Sawit.
\end{abstract}

Kata Kunci: Financial Distress dengan model Zmijewski, Laba Per Saham, Pengembalian saham

\begin{abstract}
The study in this research aims to determine the impact of Financial Distress and Earning per Share (EPS) on the Company's Stock Return (in the Oil Palm Plantation Sub-Sector listed on the Indonesia Stock Exchange (IDX) for the research period from 2015 to 2018. Factors tested namely Financial Distress and Earning per Share (EPS) as independent variables and Stock Return as the dependent variable.This research uses a measurement of the ratio scale and Purposive Sampling, so that there are 15 issuers of the Oil Palm Plantation sub-sector listed on the Indonesia Stock Exchange in this research. The study uses Descriptive Statistics through panel data regression techniques using Random Effect Model or REM testing procedures through the Eviews 9 programming test application. After testing, there is a negative
\end{abstract}


relationship from the use of the Zmijewski model to test the Financial Distress factor on Stock Returns.Meanwhile, the Earning factor per Share (EPS) no ak has an influence on Stock Return. It is also known that PT Astra Agro Lestari, Tbk (AALI) has the best financial performance and share value, while PT Gozco Plantation, Tbk (GZCO) has the worst financial performance and share value when compared to the Association of Palm Oil Sub-Sector.

Keywords: Earning Per Share (EPS), Financial Distress with model Zmijewski Stock Return

\section{Pendahuluan}

Para penanam modal sebelum melaksanakan investasi saham pada suatu emiten, mereka terlebih dulu akan melaksanakan analisis kinerja keuangan pada perseroan tersebut, dengan harapan bahwa emiten itu dapat memberikan keuntungan, yang merupakan tujuan utama yang ingin pemodal dapatkan dari kegiatan jual beli saham di Pasar Modal. Pendukung keuangan potensial menggunakan strategi atau prosedur yang berbeda untuk memperoleh keuntungan, baik dengan menggunakan analisa teknikal maupun fundamental, melalui pemeriksaan mereka sendiri terhadap perilaku bursa ataupun melalui jasa kantor penyidik pasar modal, yaitu melalui pialang, jasa perusahaan sekuritas ataupun para manajer investasi.

Pengembalian keuntungan saham dibedakan menjadi dua, yaitu pengembalian realisasi (pengembalian yang terjadi atau dapat juga disebut sebagai pengembalian yang sebenarnya) dan pengembalian yang diekspektasi (pengembalian yang diharapkan oleh pemberi dana).

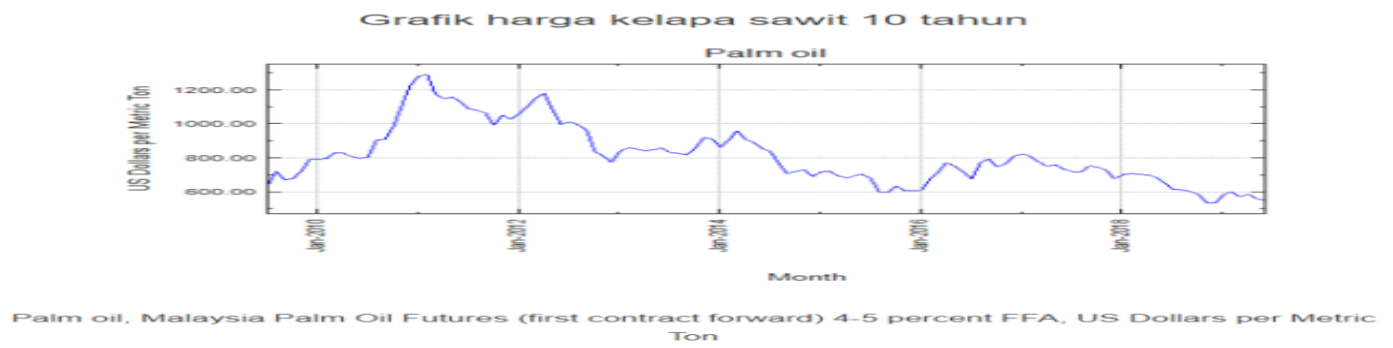

Gambar 1: Grafik harga kelapa sawit dalam kurun waktu 10 tahun Sumber: www.sahamok.com/grafik-harga-komoditi/kelapa-sawit-2

Melihat gambar di atas, terjadi penurunan biaya minyak sawit dunia selama 10 tahun, yang dimulai pada tahun 2010 hingga 2018, yang juga memperlihatkan penurunan indeks sektor perkebunan secara tajam, sehingga berpengaruh pada tingkat pengembalian saham. Selain gambar di atas, di bawah ini juga ditampilkan pergerakan pengembalian saham yang diperoleh melalui hasil kalkulasi Abnormal Return yang diterapkan pada perusahaan Sub Sektor Perkebunan Kelapa Sawit yang tercatat di Bursa Efek Indonesia. 


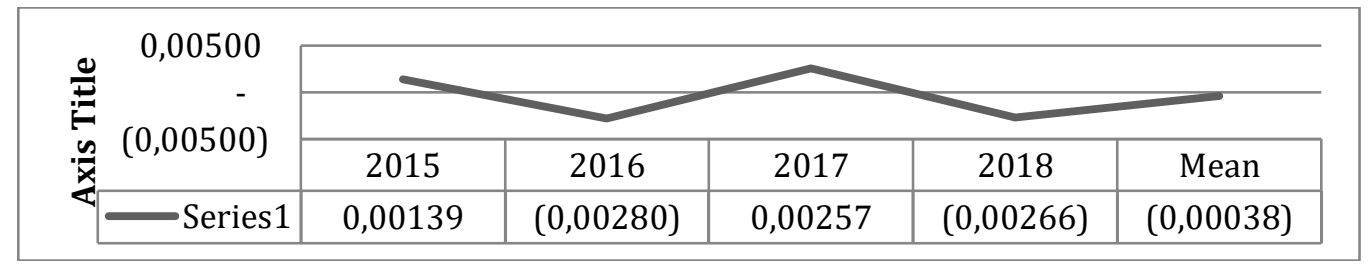

Gambar 2: Return Saham (Rata-rata nilai Abnormal Return) Perusahaan Sub Sektor Perkebunan Kelapa Sawit tahun 2015 sampai tahun 2018

Sumber: www.idx.co.id (data yang diolah)

Yang disajikan dari Gambar 2, terjadi penurunan return saham yang dialami oleh perusahaan Sub Sektor Perkebunan Kelapa Sawit di tahun 2016 dan 2018 dengan nilai return saham negatif dan di bawah nilai normal. Selanjutnya, jika dikaitkan pada Gambar 1 di tahun 2016 dan 2018 pada diagram tersebut, terjadi penurunan harga jual kelapa sawit dunia. Yang berakibat pada adanya kaitan antara harga jual kelapa sawit dunia dengan return saham yang dihasilkan oleh perusahaan kelapa sawit di Indonesia di tahun 2016 dan 2018.

Disampaikan Damodaran (2012) untuk terhindar dari kesulitan keuangan, manajemen suatu perusahaan harus melaksanakan pengawasan terhadap kinerja perusahaan. Terdapat dua hal yang menyebabkan suatu perusahaan mengalami kebangkrutan, yaitu faktor global yang bersifat umum (makro) dan juga faktor dari dalam perusahaan itu sendiri, yakni:

- Disebabkan oleh masalah kesulitan arus kas, dimana pembiayaan operasional perusahaan lebih besar dibandingkan penghasilannya.

- Disebabkan karena besarnya hutang perusahaan, dimana hutang yang besar tersebut tidak mampu ditutupi dan dilunasi oleh perusahaan.

- $\quad$ Akibat kerugian yang disebabkan oleh aktivitas operasional perusahaan, sehingga kerugian tersebut menyebabkan perusahaan membayar beban yang lebih besar yang dibiayai dari penerimaan perusahaan dan menyebabkan arus kas menjadi negatif.

Beberapa organisasi bisa saja mudah untuk mengatasi hal tersebut di atas, namun jika pemicu kebangkrutannya disebabkan oleh keadaan dari luar perusahaan yang lebih bersifat global (makro), maka akan sulit untuk diatasi oleh perusahaan itu sendiri. Hal ini sejalan dengan riset yang telah dilakukan oleh Julini, Siahaan, Sinaga, dan Purba (2015), dimana dijelaskan gagasan terkait teknik menghitung kesulitan keuangan (financial distress) melalui perhitungan Altman ZScore, kesimpulan risetnya bahwa financial distress memiliki pengaruh yang positif pada return saham.

Merujuk pada riset terdahulu, diungkapkan oleh Nathaniel (2008), dimana Earning per Share (EPS) tidak berdampak kritis terhadap return saham. Sementara itu, riset dari Putra dan Kindangen (2016); Sinaga (2019); Purnamasari, DP. dan Satriawan S. (2014); serta oleh Gunadi dan Kesuma (2015), dimana hasil risetnya yaitu Earning Per Share (EPS) tidak memiliki pengaruh pada Return Saham.

\section{Tinjauan Pustaka}

\subsection{Return Saham}

Return saham menurut Hartono, J. (2016), diartikan secara spesifik sebagai hasil yang diperoleh dari suatu kegiatan penanaman modal. Metode untuk menghitung return saham juga menggunakan referensi dari buku tersebut, yaitu: 
1. Ukuran keuntungan yang disampaikan bergantung pada ukuran keuntungan yang diperoleh dari bisnis dan strategi sirkulasi keuntungan.

$$
\text { Return Total }=\frac{(P t-P t-1)+D t}{P t-1}
$$

Dimana:

$$
\begin{array}{ll}
\text { PtPt } & =\text { Harga saham pada saat ini } \\
P t-1 & =\text { Harga saham periode lalu } \\
D t D t & =\text { Keuntungan tunai yang dibayarkan }
\end{array}
$$

2. Namun, jika suatu organisasi tidak melaksanakan pembagian dividen tunai secara berkala kepada para investornya, pengembalian saham dapat ditentukan sebagai berikut:

$$
\text { Return Saham }=\frac{(P t-(P t-1))}{P t-1}
$$

Sehingga disimpulkan bahwa perhitungan return dalam riset ini yaitu dengan menggunakan hasil dari pengurangan harga saham periode ini terhadap harga periode lalu, serta jenis return yang digunakan adalah realized return.

\subsection{Abnormal Return}

Seperti yang dikemukakan oleh Hartono, J. (2016), return abnormal adalah selisih dari return realisasi atas return normal, yang ditunjukkan melalui:

$$
R T N_{i, t}=R_{i, t}-E\left[R_{i, t}\right]
$$

Penjelasan:

$$
\begin{aligned}
& R T N_{i, t}=\text { Return abnormal dari sekuritas pertama pada saat- } \mathrm{t} \\
& R_{i, t}=\text { Realisasi Return melalui sekuritas pertama pada saat- } \mathrm{t} \\
& E\left[R_{i, t}\right]=\text { Return yang diharapkan dari sekuritas pertama pada saat-t }
\end{aligned}
$$

Return yang sebenarnya atau disebut juga dengan Actual Return, yaitu pengembalian saham yang diperoleh melalui selisih antara nilai penutupan saham pada hari ini dengan nilai saham pada hari sebelumnya. Sementara itu, dalam riset ini untuk mengetahui nilai pengembalian saham yang diharapkan atau yang biasa disebut return ekspektasi yaitu dengan menggunakan "Market Adjusted Model", dimana Indeks Harga Saham Gabungan yang disingkat dengan IHSG digunakan dalam perhitungannya yaitu selisih antara nilai IHSG pada suatu hari dengan nilai hari sebelumnya.

\subsection{Financial Distress (Kesulitan Keuangan )}

Merujuk pada riset Hossari dan Rahman (2005) yang disampaikan kembali oleh Fachrudin (2008), bahwa penggunaan "Teknik Multivariat" yang diambil dari lima puluh tiga riset yang dilaksanakan pada tahun 1966 sampai dengan tahun 2002, yang menghasilkan empat puluh delapan rasio keuangan terpopuler, namun yang digunakan dalam model Zmijewski, hanya menggunakan tiga rasio keuangan saja yang menduduki posisi teratas, yaitu: 1) kegagalan bank, 2) kegagalan bisnis, dan 3) kesulitan keuangan perusahaan. Maka Model Zmijewski yang 
digunakan dalam riset ini, untuk mengetahui level kebangkrutan pada Perusahaan Sub Sektor Kelapa Sawit.

Selain itu, penggunaan model Zmijewski yang digunakan dalam penelitian ini untuk dapat mengukur tingkat kesulitan keuangan pada sub sektor perkebunan kelapa sawit juga didasarkan pada pemahaman pada penelitian yang dilakukan oleh Anandarajan, et al. (2001) yang dikutip dari Fachrudin (2008), bahwa Model Zmijewski yang dicetuskan pada tahun 1984 dapat digunakan untuk mengetahui prediksi dari awal kebangkrutan suatu entitas dalam industri secara umum dan bukan pada industri tertentu.

Kriteria pengukurannya didapatkan melalui perhitungan berikut:

$$
b^{*}=-4.803-3.6 \mathrm{ROA}+5.4 \mathrm{FNL}-0.1 \mathrm{LIQ}
$$

Penjelasannya nilai $\mathbf{b}^{*}$ yaitu menunjukkan kemungkinan terjadi likuidasi pada perusahaan yang diteliti, dimana bahwa semakin besar nilai "b", maka peluang entitas yang diteliti menuju kondisi bangkrut, akan menjadi lebih tinggi.

Diketahui dalam rumus tersebut, terdapat tiga rasio keuangan sesuai dengan model Zmijewski, dan ketiga pengukuran rasio keuangan tersebut ialah yang digunakan dalam penelitian ini, yaitu: ROA = Return on Asset atau Pendapatan Bersih pada Total Aktiva FNL $=$ Total Debt to Asset atau Total Kewajiban terhadap Total Aktiva LIQ $=$ Current Assets to Current Liabilities atau Aktiva Lancar pada Kewajiban Lancar

Merujuk pada riset Hossari dan Rahman (2005) yang disampaikan kembali oleh Fachrudin (2008), bahwa penggunaan "Teknik Multivariat" yang diambil dari lima puluh tiga riset yang dilaksanakan pada tahun 1966 sampai dengan tahun 2002, menghasilkan empat puluh delapan rasio keuangan terpopuler, namun yang digunakan dalam model Zmijewski, hanya menggunakan tiga rasio keuangan saja yang menduduki posisi teratas, yaitu: 1) kegagalan bank, 2) kegagalan bisnis, dan 3) kesulitan keuangan perusahaan. Maka Model Zmijewski yang digunakan dalam riset ini, untuk mengetahui level kebangkrutan pada Perusahaan Sub Sektor Kelapa Sawit.

\subsection{Earning per Share (EPS)}

Laba Per Saham atau yang biasa disebut dengan EPS, didefinisikan oleh Darmadji dan Fakhruddin (2006) sebagai proporsi yang menunjukkan porsi pendapatan per lembar saham yang dimiliki. Persamaan manfaat per saham adalah sebagai berikut:

$$
\text { Laba per Saham }=\frac{\text { LabaBersih }}{\text { JumlahSaham yang beredar }}
$$

Seperti yang disampaikan oleh Tandelilin (2017), bahwa laba per saham (EPS) adalah bagian penting utama sebelum Price Earning Ratio (PER) yang harus dipertimbangkan untuk menganalisa suatu entitas. Dengan mengetahui nilai Laba per Saham (EPS), berarti bahwa besarnya laba yang diperoleh entitas tersebut juga dapat diketahui, dan seseorang yang ingin berinvestasi pada perusahaan tersebut, dapat memperkirakan jumlah keuntungan yang akan diperoleh. 


\subsection{Pengaruh Financial Distress terhadap Return Saham}

Menurut Julini, Siahaan, Sinaga dan Purba (2015) agar terhindar dari terjadinya kesulitan keuangan di suatu perusahaan, salah satu kewajiban manajemen perusahaan yaitu dengan menerapkan kinerja perusahaan yang baik. Hasil risetnya menunjukkan bahwa kesulitan keuangan yang menggunakan perhitungan "Altman Z-Score" memiliki dampak positif dan tidak signifikan terhadap return saham. Namun, hasil penelitian yang berbeda yang dilakukan oleh Wulandari, Norita, dan Iradianty (2016), bahwa "Ohlson Score" yang digunakan untuk menghitung estimasi kesulitan keuangan berdampak negatif pada return saham pada 9 perusahaan sub sektor tekstil dan garmen yang dipilih dengan purposive sampling, dimana kondisinya pada saat diteliti bahwa perusahaan tersebut sedang mengalami indikasi awal kebangkrutan.

Model Zmijewski digunakan untuk mengetahui prediksi kesulitan keuangan yang terjadi pada Perusahaan Sub-Sektor Kelapa Sawit. Hal ini disebabkan karena tiga rasio keuangan dalam model Zmijewski merupakan peringkat tiga besar rasio keuangan utama yang diungkapkan dalam penelitian Hossari dan Rahman (2005) dalam Fachrudin (2008), yaitu Laba Bersih terhadap Total Aktiva, Total Hutang terhadap Total Aktiva, serta Aktiva Lancar terhadap Kewajiban Lancar. Untuk itu dalam penelitian ini, dapat disimpulkan Hipotesis pertama ialah:

H1 : Financial Distress memiliki pengaruh pada return saham.

\subsection{Pengaruh Earning per Share terhadap Return Saham}

Riset yang telah dilaksanakan oleh Sinaga (2019) yang kontradiktif dengan teori, menyimpulkan bahwa EPS tidak berdampak terhadap return saham, diperoleh dari analisis statistik deskriptif pada variabel EPS yang memiliki sebaran data yang kurang baik, dan ditunjukkan dengan nilai standar deviasi EPS jauh lebih besar dibandingkan dengan nilai EPS itu sendiri. Disampaikan juga bahwa perusahaan yang dijadikan sampel penelitian yaitu MLBI dan DLTA, memberikan return saham yang jauh melebihi rata-rata return yang diberikan oleh perusahaan pesaing lainnya dalam satu sektor perusahaan. Selain itu, jumlah saham yang beredar atas kedua perusahaan tersebut, jauh lebih kecil dibandingkan perusahaan lain yang menyebabkan laba per lembar sahamnya menjadi jauh lebih besar dari rata-rata EPS yang diberikan perusahaan industri sejenis.

Oleh karena hal tersebut sehingga tertarik untuk membuktikan teori bahwa semakin besarnya nilai EPS entitas, maka menjadi semakin menguntungkan pemilik saham entitas tersebut, karena EPS besar menunjukkan laba entitas tersebut juga besar, yang menyebabkan calon pemilik saham tertarik untuk berinvestasi, yang berdampak pada naiknya harga dan return saham entitas tersebut. sehingga, hipotesis kedua riset ini yaitu:

H2: Earning per Share (EPS) memiliki pengaruh pada return saham.

\section{Metodologi Penelitian}

Beberapa kategori sampel yang berkaitan dengan riset ini yaitu:

1) Perusahaan dalam kategori sub Sektor Perkebunan Kelapa Sawit yang tercatat di BEI antara tahun 2015 sampai 2018.

2) Perusahaan dalam kategori sub sektor Perkebunan Kelapa Sawit yang selalu mempublikasikan informasi laporan keuangan antara tahun 2015 sampai dengan tahun 2018. 
3) Perusahaan dalam kategori Sub Sektor Perkebunan Kelapa Sawit yang berinformasi data sangat lengkap dalam kurun waktu tahun 2015-2018 untuk menunjang riset.

Maka kesimpulan data yang digunakan untuk riset ini yaitu:

- Total populasi data riset ini sebanyak delapan belas (18) perusahaan dalam kategori sub sektor perkebunan kelapa sawit yang listed di BEI.

- Sampel dalam riset ini sebanyak limabelas (15) perusahaan dalam kategori perusahaan di atas, sebab terdapat tiga perusahaan yang tidak memenuhi kriteria uji dalam riset ini dikarenakan data publikasi laporan keuangannya tidak lengkap yaitu ANDI, MGRO, dan GOLL.

Di riset ini, digunakan teknik analisis data panel regression atau panel pooled data.

\section{Estimasi Model Data Panel Regression menggunakan Random Effect}

Merujuk hasil olah data yang menggunakan program eviews versi 9, persamaan regresi yang diperoleh yakni:

$$
\text { Return Saham }=(-0,000448)+(-7,79 \mathrm{E}-05)(\mathrm{FD})+(-1,44 \mathrm{E}-06)(\mathrm{EPS})
$$

Dengan penjelasan sebagai berikut:

- $\quad$ Angka - 0,000448 mengandung arti bahwa prediksi mengenai Return Saham (Y) pada saat kedua variabel bebas yaitu Financial Distress dan Earning per Share (EPS) dianggap konstan atau bernilai nol, yang berdampak pada perubahan rata-rata nilai Return Saham.

- Angka koefisien regresi untuk Financial Distress adalah - 7,79E-05 dan bernilai negatif, berarti terdapat hubungan yang berlawanan antara Financial Distress dengan Stock Return, atau setiap kenaikan Financial Distress malah menurunkan Stock Return sebesar 7,79E-05 kali lipatnya.

- $\quad$ Angka koefisien regresi Earning per Share (EPS) adalah - 1,44E-06 dan bernilai negatif, yang berarti terdapat hubungan yang berlawanan antara EPS dengan Stock Return, atau setiap kenaikan Earning per Share (EPS), malah menurunkan Stock Return sebesar 1,44E06 kali lipatnya.

\section{Uji Hipotesis}

1) Pengujian Signifikansi Simultan (Uji Statistik-F)

Merujuk pada hasil olah data, bahwa nilai probabilitas uji statistik-F bernilai 0,028989 lebih rendah dari standar signifikansi tingkat 0,05 yang berarti bahwa dalam riset ini perhitungan model regresinya layak untuk digunakan.

2) Koefisien Determinasi

Nilai koefisien determinasi yang didapat dari hasil olah data ialah $11,7 \%$, yang berarti bahwa Financial Distress dan Earning per Share (EPS) berdampak pada perubahan penambahan Stock Return sebesar 11,7\% pada perusahaan yang diuji, sedangkan sisanya $88,3 \%$ dipengaruhi oleh unsur lainnya atau faktor yang tidak dianalisis dalam riset ini.

3) Hasil Uji Hipotesis-t

Uji variabel bebas dalam riset ini, hasilnya yaitu: 
Tabel 1: Hasil uji hipotesis (sub hipotesis)-t

\begin{tabular}{|l|l|l|}
\hline Variable & t-Statistic & Prob. \\
\hline FINANCIAL_DISTRESS -2.475852 & 0.0163 \\
\hline EPS & -0.492296 & 0.6244 \\
\hline C & -0.553673 & 0.5820 \\
\hline \hline
\end{tabular}

Tabel 2: Hasil uji hipotesis-t

\begin{tabular}{|c|c|c|c|c|c|}
\hline Variabel & $\frac{\text { t-Hitung }}{\text { Model Reg }}$ & t-Tabel & $\alpha$ Hitung & Tabel & Keterangan \\
\hline $\begin{array}{l}\text { Financial } \\
\text { Distress }\left(\mathrm{X}_{1}\right)\end{array}$ & -2.475852 & 2.00247 & 0.0163 & 0.05 & $\begin{array}{l}\text { Terdap at pengarnih dan signifilan dengan } \\
\text { korelasi negatif }\end{array}$ \\
\hline $\operatorname{EPS}\left(\mathrm{X}_{1}\right)$ & -0.492296 & 2.00247 & 0.6244 & 0.05 & Tidak terdapat pengaruh \\
\hline
\end{tabular}

Disimpulkan dari tabel 2, bahwa nilai Financial Distress dan nilai Laba per Saham (EPS), yaitu:

1) $\mathrm{H}_{0} 1$ ditolak dan $\mathrm{H}_{\mathrm{a}} 1$ diterima, karena nilai probabilitasnya lebih kecil dari 0,05. Sedangkan, nilai thitung lebih besar dari ttabel, yang berarti bahwa faktor Financial Distress berdampak secara signifikan namun berlawanan arahnya terhadap Stock Return.

2) $\mathrm{H}_{0} 2$ diterima dan $\mathrm{H}_{\mathrm{a}} 2$ ditolak, karena nilai probabilitasnya lebih besar dari 0,05 . Sedangkan, nilai thitung lebih kecil dari ttabel, yang berarti bahwa EPS tidak memiliki pengaruh pada Stock Return.

\section{$4 \quad$ Hasil Penelitian dan Pembahasan}

\subsection{Pengaruh Financial Distress Terhadap Return Saham}

Melalui hasil uji hipotesis dalam riset ini, diperoleh hasil t-statistic financial distress sebesar 2,475852 dengan probabilitinya 0,0163 yang nilainya lebih kecil dibandingkan dengan tingkat signifikansi atau $0,0163<0,05$, maka ditarik kesimpulan bahwa hasil uji dari hipotesis pertama adalah diterima, yang berarti bahwa financial distress berpengaruh pada Stock Return. Dapat disimpulkan bahwa, terdapat pengaruh yang berlawanan dari kedua variabel tersebut, dimana semakin tinggi kondisi kesulitan keuangan (financial distress) menyebabkan semakin rendah pemberian stock return pada perusahaan yang diteliti yaitu sub sektor perkebunan kelapa sawit pada tahun uji 2015 sampai 2018. Sehingga, hasil penelitian sejalan dengan penelitian yang dilakukan oleh Wulandari, Norita, dan Iradianty (2016), yaitu adanya pengaruh signifikan dari prediksi kebangkrutan $O$-Score terhadap Stock Return pada perusahaan yang diteliti, yang mana semakin besar score Ohlson membuat semakin rendah Stock Returnnya.

Adapun dalam riset ini, yang mengalami kesulitan keuangan paling tinggi adalah GZCO (Gozco Plantation) terjadi pada tahun 2015 hingga 2018, yang menyebabkan return saham yang dibagikan emiten ini ialah yang paling rendah jika dibandingkan perusahaan lain. Sebaliknya dalam kategori perusahaan yang sama, AALI (Astra Agro Lestari) mengalami risiko kesulitan keuangan yang paling rendah dan membagikan return saham yang paling besar kepada para investornya.

\subsection{Pengaruh Earning Per Share (EPS) terhadap Stock Return}

Hasil uji hipotesis dalam riset ini, diperoleh nilai uji t-statistic sebesar -0,492296 dengan probabilitas 0,6244 yang lebih besar dari tingkat signifikansi 0,05 atau 0,6244 >0,05, yang menunjukkan bahwa EPS tidak memiliki pengaruh pada Stock Return pada perusahaan yang 
diteliti. Dari hasil uji regresi data panel riset ini bahwa hasil uji hipotesis kedua ialah ditolak, atau dapat diartikan faktor EPS tidak berdampak pada return saham pada sektor perusahaan yang diteliti. Hasil riset ini sesuai dengan penelitian Aditya dan Isnurhadi (2013) bahwa EPS tidak berdampak pada return saham pada perusahaan infrastruktur, utilitas, dan transportasi yang berarti bahwa teori mengenai EPS dan Return Saham kontradiktif dengan pemikiran investor. Penelitian Putra \& Kindangen (2016), menunjukkan hasil yang sejalan yaitu EPS tidak berpengaruh pada Return Saham.

Penjelasan mengenai hasil uji riset ini bahwa EPS tidak berpengaruh pada return Saham, yaitu:

- Bahwa nilai EPS atau perbandingan dari laba bersih terhadap harga per lembar saham perusahaan, bukanlah satu-satunya faktor penentu yang dapat dijadikan pertimbangan bagi calon pemegang saham yang ingin membeli saham suatu emiten.

- Meskipun perbandingan Laba per Saham yang beredar di perusahaan meningkat, belum tentu tingkat pembagian keuntungan atas kepemilikan saham emiten tersebut juga akan meningkat, dikarenakan ada banyak faktor lain yang bisa mempengaruhi proporsi pembagian return saham suatu emiten.

- Walaupun dalam teori disampaikan semakin tinggi EPS akan mengakibatkan semakin tinggi return saham, tetapi kebanyakan dari pembeli saham lebih tertarik untuk mendapatkan keuntungan jangka pendek atau capital gain, yaitu selisih antara harga beli dengan harga jual saham emiten tersebut.

- $\quad$ Merujuk pada hasil uji statistik deskriptif yang dilakukan, yaitu nilai rata-rata (mean) yang jauh dibawah standar deviasi, serta selisih antara nilai minimum dan maksimumnya sangat tinggi, yang berarti bahwa terjadi penyebaran data yang kurang baik pada variabel EPS sub sektor kelapa sawit yang diteliti dalam riset ini. Selain itu, nilai probabilitas yang lebih besar dari tingkat signifikansi 0,05 dan nilai thitung lebih kecil dari ttabel, maka dapat disimpulkan bahwa EPS tidak berpengaruh pada return saham dalam penelitian ini.

\section{$5 \quad$ Simpulan dan Saran}

Simpulan dari riset ini berdasarkan pada pembahasan yang telah disampaikan, yaitu:

1. Adanya pengaruh signifikan tetapi berlawanan arah antara Financial Distress dengan Return Saham. Yaitu bahwa semakin tinggi nilai Financial Distress, maka menjadi semakin rendah Return Saham yang diberikan pada perusahaan yang diteliti. Begitupun sebaliknya.

2. EPS tidak memiliki pengaruh pada Return Saham, yang berarti bahwa meningkatnya nilai EPS tidak berdampak pada besar atau kecilnya return saham yang dibagikan oleh emiten kepada investornya.

3. AALI (Astra Agro Lestari) ialah perusahaan yang masuk dalam kategori terbaik pada subsektor industri kelapa sawit yang diteliti dalam riset ini melalui analisa perhitungan model Zmijewski, dimana memiliki kinerja keuangan yang sangat baik dan tidak terkendala kesulitan keuangan. Selain itu memiliki kinerja saham yang terbaik, dengan nilai EPS yang tinggi dan harga penutupan saham per tahun yang paling tinggi jika dibandingkan dengan nilai nominal sahamnya selama periode 2015 sampai 2018.

4. Namun, dengan analisa perhitungan yang sejalan dalam riset ini, bahwa GZCO (Gozco Plantation) merupakan perusahaan yang memiliki kinerja keuangan yang paling buruk, nilai EPS yang sangat rendah dan harga pengembalian saham yang paling rendah, serta harga saham penutupan akhir setiap tahun yang terus menurun dan jauh lebih rendah dari nilai nominal sahamnya. Selain itu, MAGP (Multi Agro Gemilang); JAVA (Jaya Agra Wattie) dan UNSP (Bakrie Sumatera Plantation), juga memiliki kinerja keuangan yang 
buruk, nilai EPS dan Return Saham yang rendah, serta harga saham penutupan per tahunnya yang terus menurun dan lebih rendah daripada nilai nominal sahamnya.

Masukkan yang dapat diberikkan berdasarkan simpulan yang sudah diuraikan diantaranya adalah:

1. Ditujukan kepada perusahaan dalam industri yang diteliti dalam riset ini, khususnya GZCO, JAVA, MAGP dan UNSP disarankan untuk memberi perhatian khusus dan meningkatkan pengelolaan kinerja Return terhadap Aktiva yang dimiliki (ROA), perbaikan pengelolaan utang dan kewajiban perusahaan, dan pengelolaan likuiditas khususnya pada indikator Rasio Hutang Lancar, serta untuk dapat mengantisipasinya adalah dengan menerapkan model prediksi kebangkrutan Zmijewski. Selain daripada itu, agar bisa meningkatkan laba perusahaan yang bisa menaikkan EPS, agar calon penanam modal tertarik berinvestasi pada empat perusahaan tersebut.

2. Kepada calon penanam modal atau investor yang berminat untuk membeli saham dan menanamkan modalnya pada perusahaan dalam industri di riset ini, sebaiknya terlebih dahulu dapat melakukan analisa kinerja keuangan dengan menghitung prediksi kebangkrutan perusahaan tersebut menggunakan metode zmijewski. Jika hasil perhitungannya menghasilkan score besar berarti harus dihindari, karena kondisi keuangan emiten tersebut sedang buruk dan berdampak pada kecilnya keuntungan yang didapatkan dari investasinya, begitupun sebaliknya.

3. Untuk peneliti berikutnya yang tertarik melaksanakan dengan tema yang sama, saya referensikan untuk menggunakan metode lainnya dalam memprediksi kebangkrutan emiten, misalnya menggunakan metode Grover yang lebih lengkap dari zmijewski, atau bisa menggabungkan tiga metode sekaligus yaitu "Springate, Ohlon Score dan Altman ZScore", agar hasil penelitiannya lebih lengkap dan lebih mumpuni. Atau dapat juga dengan menggunakan variabel kinerja keuangan lainnya selain rasio profitabilitas sehingga hasil cakupan analisisnya menjadi lebih luas.

\section{Daftar Pustaka}

Aditya, K., \& Isnurhadi. (2013). Analisis Pengaruh Rasio Lancar, Rasio Perputaran Total Aktiva, Debt To Equity Ratio, Return On Equity, Dan Earning Per Share Terhadap Return Saham Perusahaan Sektor Infrastruktur, Utilitas, Dan Transportasi Yang Terdaftar Di BEI Periode 2007-2011. Jurnal Manajemen dan Bisnis Sriwijaya (JMBS), Vol.11, No.4, Desember 2013. ISSN 1412-4521.

Damodaran, A. (2012). Investment Valuation (3rd Edition). New York: John Wiley \& Sons. Fachrudin, K. A. (2008). Kesulitan Keuangan Perusahaan dan Personal. Medan: USU Press.

Gunadi, G. G., \& Kesuma, I. W. (2015). Pengaruh ROA, DER, EPS Terhadap Return Saham Perusahaan Food And Beverage BEI. E-Jurnal Manajemen Unud, 1636-1647 (Vol. 4, No. 6) .

Hartono, J. (2016). Teori Portofolio dan Analisis Investasi ( Edisi 10 ). Yogyakarta: BPPE.

Julini, D., Siahaan, Y., Sinaga, M., \& Purba, R. (2015). Pengaruh Financial Distress (Altman ZScore) Terhadap Return Saham Pada Perusahaan Sektor Aneka Industri Yang Terdaftar Di Bursa Efek Indonesia. SULTANIST: Jurnal Manajemen dan Keuangan STIE Sultan Agung, (Vol 3, No 1).

Nathaniel, N. (2008). Analisis Faktor-Faktor Yang Mempengaruhi Return Saham (Studi Pada Saham-saham Real Estate and Property di Bursa Efek Indonesia Periode 2004-2006). eprints.undip.ac.id. Semarang, Jawa Tengah, Indonesia: Universitas Diponegoro.

Purnamasari, K., DP, E. N., \& Satriawan S, R. A. (2014). Pengaruh Current Ratio (CR), Debt To Equity Ratio (DER), Return On Equity (ROE), Price Earning Ratio (PER), Dan Earning Per Share (Eps) Terhadap Return Saham Pada Perusahaan Property And Real Estate Yang Terdaftar Di Bursa Efek Indonesia Tahun 2009-2011. Jom FEKON, Vol 1 No. 2. 
Putra, F. E., \& Kindangen, P. (2016). Pengaruh Return On Asset (ROA), Net Profit Margin (NPM), Dan Earning Per Share (EPS) Terhadap Return Saham Perusahaan Makanan Dan Minuman Yang Terdaftar Di Bursa Efek Indonesia (Periode 2010-2014) . Jurnal EMBA Jurnal EMBA Vol.4 No.4 September 2016, 235-245.

Sinaga, R. V. (2019). Pengaruh Inventory Turnover (ITO), Debt To Equity Ratio (DER), Return On Asset (ROA), Earning Per Share (EPS), dan Price Earning Ratio (PER) Terhadap Return Saham Pada Perusahaan Food And Beverage Yang Terdaftar di Bursa Efek Indonesia. Jurnal Manajemen dan Bisnis (JMB) Volume 19 No. 1 Universitas Katolik Santo Thomas Medan, 29-46.

Tandelilin, E. (2017). Pasar Modal (Analisis Investasi dan Manajemen Portofolio). Yogyakarta: PT Kanisius.

Wulandari, A. P., Norita, \& Iradianty, A. (2016). Pengaruh Prediksi Kebangkrutan Ohlson Score (O-Score) Terhadap Return Saham (Studi Pada Perusahaan Sub Sektor Tekstil dan Garmen Yang Listing di BEI Tahun 2010-2014). e-Proceeding of Management (pp. 101108). Bandung: Telkom University. 